\title{
Effects of Fertilizer Source and Rate on Zinnia Cut Flower Production in a High Tunnel
}

\author{
Guihong Bi ${ }^{1, *}$, Tongyin $\mathrm{Li}^{1}{ }^{1}$, Mengmeng Gu${ }^{2}{ }^{\mathbb{D}}$, William B. Evans ${ }^{3}$ and Mark Williams ${ }^{4}$ \\ 1 Department of Plant and Soil Sciences, Mississippi State University, \\ Mississippi State, MS 39762, USA; t1665@msstate.edu \\ 2 Department of Horticultural Sciences, Texas A\&M AgriLife Extension Service, \\ College Station, TX 77843, USA; mgu@tamu.edu \\ 3 Up In Farms Food Hub, Jackson, MS 39216, USA; Wbe0416@att.net \\ 4 School of Plant and Environmental Sciences, Virginia Tech University, Blacksburg, VA 24060, USA; \\ markwill@vt.edu \\ * Correspondence: gbi@pss.msstate.edu
}

check for updates

Citation: Bi, G.; Li, T.; Gu, M.; Evans, W.B.; Williams, M. Effects of Fertilizer Source and Rate on Zinnia Cut Flower Production in a High Tunnel. Horticulturae 2021, 7, 333. https:// doi.org/10.3390/horticulturae7100333

Academic Editor: Moreno Toselli

Received: 16 August 2021

Accepted: 17 September 2021

Published: 23 September 2021

Publisher's Note: MDPI stays neutral with regard to jurisdictional claims in published maps and institutional affiliations.

Copyright: (c) 2021 by the authors. Licensee MDPI, Basel, Switzerland. This article is an open access article distributed under the terms and conditions of the Creative Commons Attribution (CC BY) license (https:// creativecommons.org/licenses/by/ $4.0 /)$.

\begin{abstract}
Sustainable nutrient management in high tunnel production is critical for optimizing crop yield and quality and improving soil health. In this study, we investigated the influence of different pre-plant composts (composted broiler litter, vemicompost, and cotton gin compost) in combination with different rates of organic or conventional fertilizer on zinnia plant growth, marketable yield of cut flower stems $(>30 \mathrm{~cm})$, and soil nutrients in a high tunnel over two years. Results showed that in general, pre-plant compost influenced plant growth, and plants that received composted broiler litter had the highest plant growth index. However, pre-plant compost did not affect the number of marketable cut stems. Fertigation during the growing season influenced the number of marketable cut stems. Comparable rates of nitrogen, from either organic or conventional fertilizer, produced similar numbers of marketable stems, suggesting that the organic fertilizer used in this study can be used as a fertilizer source for the production of zinnia cut flowers. After two years of production under the high tunnel, soil-extractable phosphorus, sodium, zinc, and pH significantly increased, suggesting that salt accumulation should be closely monitored in response to different compost or fertilizer sources with long-term production under high tunnels.
\end{abstract}

Keywords: high tunnel; organic fertilizer; conventional fertilizer; compost

\section{Introduction}

High tunnels are greenhouse-like structures, usually constructed with hoops of polyvinyl chloride (PVC) or metal covered with a stretched layer of polyethylene. High tunnels normally do not have automatic heating or cooling systems, and mainly rely on passive ventilation through roll-up sides and end wall doors [1]. High tunnels are mainly used to extend the growing season into early spring or late fall by creating a warmer environment for plant growth [2]. They also provide protection for plants from wind, rain, and severe weather conditions such as hail, reducing possible disease incidence and improving crop yield and quality [3-5]. Crops in high tunnels receive a lower level of irradiance and air movement compared to those grown in the field, and tend to develop significantly longer stems [6], which is one of the very important features for cut flowers. High tunnels have been widely used in Asia, Spain, Italy, and the Middle East for production of horticultural crops since the 1990s [7]. In the United States, high tunnels have been recognized by growers and researchers as important tools to produce vegetables, small fruits, cut flowers, and other specialty crops, and the use of high tunnels has increased rapidly in recent years [8-15]. Compared to greenhouses, high tunnels require lower construction and operating costs, providing growers with a cost-effective way to extend growing seasons and produce quality crops. The high values of these crops help growers recover their investment in one to five years and increase profitability $[10,12]$. 
Crops in high tunnels are often grown in the field soil on which the structure is built [4]. The intense and prolonged management of both crops and soil in high tunnel production associated with extended, or sometimes year-round growing seasons has raised concerns about soil fertility and possible negative effects on soil quality [16]. Sufficient and readily available fertility is required to produce crops with high yield and quality to ensure profitability. At the same time, maintaining soil health for long-term production is critical. In addition, since there is rarely significant leaching of nutrients due to the exclusion of rainfall inside high tunnels, build-up of excess nutrients from too much fertilization can lead to reduced plant quality and increase plant susceptibility to diseases and insects [17]. Knewtson et al. [16] reported that after eight years of production, salinity level (in terms of EC values) of soil under high tunnels was about two and a half times higher compared to that in the adjacent field, and the difference was five times higher when the soil was under organic management. Optimum fertility management has posed a challenge for growers and is critical for the success of high tunnel production [17,18].

Organic fertilizers have been commonly used in high tunnel production in addition to or instead of synthetic fertilizers to help improve physical and biological properties of soil in addition to supplying nutrients $[18,19]$. Organic fertilizers can improve soil physical characteristics, such as increased porosity, water retention, and saturated hydraulic conductivity [20,21]. Incorporation of organic fertilizers was reported to be helpful with increased soil biological activity, which possibly resulted from the enrichment of organic matter in the soil $[18,22]$. Generally, soil will be more productive with more organic matter [23].

One concern of using organic fertilizers is their slow release rates. Organic forms of nutrients need to undergo mineralization to become inorganic and available for plant uptake [24,25]. Mineralization occurs through the activity of heterotrophic microorganisms that require organic carbon for energy [23]. This process is especially important for plants to utilize nitrogen $(\mathrm{N})$ in the soil, which is often the limiting threshold for plant growth. In organic systems, combining pre-plant compost applications with organic fertilizer application is favored to increase nutrient availability to plants at early stages of growth [17]. However, each crop may respond differently and may have a distinct preference for a given organic fertilizer source and rate of application [26,27].

Due to the increasing consumer demand and interest in buying local, the production of locally-grown specialty cut flowers in the US has been increasing in recent years [28,29]. According to the Association of Specialty Cut Flower Growers (ASCFG), the ASCFG membership has grown by more than $150 \%$ since 2015 [30], indicating a strong increasing interest in specialty cut flowers. Zinnia is among the top five most commonly grown specialty cut flowers [29]. Traditionally, cut flowers are produced in open fields or greenhouses. High tunnels provide a viable alternative. Ortiz et al. [31] reported increased quality and yield of the cut flower zinnia (Zinnia elegans Jacq. "Benary Giant Scarlet") under high tunnels compared to field production in the Midwestern United States. However, limited research has investigated the optimal nutrient management for zinnia cut flowers in high tunnel production. The objective of this study was to investigate the influence of different pre-plant composts in combination with different rates of organic or conventional fertilizer during the growing season on zinnia plant growth, the marketable yield of cut flower stems, and soil nutrient conditions in the high tunnel production system. The research hypothesis was that fertilizer source and rate would alter plant growth, the number of cut flowers, and soil nutrients.

\section{Materials and Methods}

This experiment was conducted in a high tunnel at the Mississippi State University Truck Crops Branch Experiment Station in Crystal Springs, MS (lat. $31^{\circ} 59^{\prime} \mathrm{N}$, long. $90^{\circ} 21^{\prime} \mathrm{W}$ ). The high tunnel was $29 \mathrm{~m}$ long by $9 \mathrm{~m}$ wide, placed in full sun and oriented north to south Zinnia (Zinnia elegans) "Benary's Giant Mix" was selected for cut flower production. This is a series that has good market acceptance, produces long stems, and has large flowers. Zinnia 
seedlings grown in standard 1206-cell packs were transplanted into raised beds in the high tunnel on 8 April 2009 (Year 1). The soil in the high tunnel was Loring silt loam. The raised beds were $0.46 \mathrm{~m}$ across the top, $0.15 \mathrm{~m}$ tall, and spaced $1.37 \mathrm{~m}$ center to center, covered with black polyethylene mulch. A single drip irrigation tape with $0.3 \mathrm{~m}$ emitter spacing $(1.14 \mathrm{~L}$ per hour flow rate) was placed in the center of the bed and buried $2.5 \mathrm{~cm}$ below the top of the bed. Irrigation was supplied as needed.

Three local organic products were selected for the initial soil amendment in the high tunnel: composted broiler litter (Currie Farms, Raleigh, MS, USA), vermicompost (Church Hill Worm Farm, Church Hill, MS, USA), and cotton gin compost (Bolton, MS, USA). All products are locally available in large quantities, and in ready-to-use forms. Nutrient analysis of the three composts showed that the composted broiler litter generally had higher levels of nutrient elements, especially phosphorus $(\mathrm{P})$, potassium $(\mathrm{K})$, magnesium $(\mathrm{Mg})$, sulfur $(\mathrm{S})$, iron $(\mathrm{Fe})$, zinc $(\mathrm{Zn})$, sodium $(\mathrm{Na})$, copper $(\mathrm{Cu})$, and manganese $(\mathrm{Mn})$, compared to vermicompost and cotton gin compost (Table 1$)$.

Table 1. Nutrient analysis of pre-plant composts used in a high tunnel production of zinnia "Benary's Giant Mix".

\begin{tabular}{|c|c|c|c|c|c|c|c|c|}
\hline Compost & $\begin{array}{c}\mathrm{N} 1 \\
\%\end{array}$ & $\begin{array}{c}P \\
\mathrm{mg} \mathrm{kg}^{-1}\end{array}$ & $\begin{array}{c}\mathrm{K} \\
\mathrm{mg} \mathrm{kg}^{-1}\end{array}$ & $\begin{array}{c}\mathrm{Ca} \\
\mathrm{mg} \mathrm{kg}^{-1}\end{array}$ & $\begin{array}{c}\mathrm{Mg} \\
\mathrm{mg} \mathrm{kg}^{-1}\end{array}$ & $\begin{array}{c}\mathrm{S} \\
\mathrm{mg} \mathrm{kg}^{-1}\end{array}$ & $\begin{array}{c}\mathrm{Al} \\
\mathrm{mg} \mathrm{kg}^{-1}\end{array}$ & $\begin{array}{c}\text { Fe } \\
\mathrm{mg} \mathrm{kg}^{-1}\end{array}$ \\
\hline Composted Broiler Litter & 2.15 & 19,500 & 24,700 & 34,400 & 7650 & 6210 & 1710 & 3660 \\
\hline Vermicompost & 1.04 & 2840 & 4870 & 60,500 & 3270 & 2850 & 3050 & 3350 \\
\hline \multirow[t]{2}{*}{ Cotton Gin Compost } & 3.70 & 5110 & 8320 & 25200 & 4380 & 4130 & 337 & 631 \\
\hline & $\begin{array}{c}\mathrm{Zn} \\
\mathrm{mg} \mathrm{kg}^{-1}\end{array}$ & $\begin{array}{c}\mathrm{Na} \\
\mathrm{mg} \mathrm{kg}^{-1}\end{array}$ & $\begin{array}{c}\mathrm{Cu} \\
\mathrm{mg} \mathrm{kg}^{-1}\end{array}$ & $\begin{array}{c}B \\
\mathrm{mg} \mathrm{kg}^{-1}\end{array}$ & $\begin{array}{c}\mathrm{Mn} \\
\mathrm{mg} \mathrm{kg}^{-1}\end{array}$ & $\begin{array}{c}\text { Moisture } \\
\%\end{array}$ & $\begin{array}{c}\text { Soluble } \\
\text { Salts } \\
\text { dS m }^{-1}\end{array}$ & $\mathrm{pH}$ \\
\hline Composted Broiler Litter & 470 & 7230 & 351 & 38.7 & 590 & 21.7 & 0.1 & 8.9 \\
\hline Vermicompost & 65.6 & 637 & 40.9 & 17.7 & 165 & 30.9 & 0.1 & 7 \\
\hline Cotton Gin Compost & 41.3 & 171 & 10.5 & 55.1 & 273 & 7.6 & 0.1 & 6.7 \\
\hline
\end{tabular}

${ }^{1} \mathrm{~N}=$ nitrogen; $\mathrm{P}=$ phosphorus; $\mathrm{K}=$ potassium; $\mathrm{Ca}=$ calcium; $\mathrm{Mg}=$ magnesium; $\mathrm{S}=$ sulfur; $\mathrm{Al}=$ aluminum; $\mathrm{Fe}=$ iron; $\mathrm{Zn}=$ zinc; $\mathrm{Na}=$ sodium $; \mathrm{Cu}=$ copper $\mathrm{B}=$ boron; $\mathrm{Mn}=$ manganese .

A liquid catfish processing byproduct MultiBloom (Hydrolysate Company of America, Isola, MS, USA) was used as the organic fertilizer source for fertigation after transplanting. Peter's 20-10-20 water soluble fertilizer (20N-4.3P-16.7K; The Scotts Company, Marysville, $\mathrm{OH}, \mathrm{USA}$ ) was used as a conventional fertilizer source in comparison to the organic fertilizer. This study was a $4 \times 5$ factorial arrangement of treatments in a split plot design. The compost treatment served as the main plot, and fertigation treatment as the sub plot. Each block included four pre-plant compost treatments: composted chicken broiler litter, vermicompost, cotton gin compost, and control (no compost). The compost was applied at 8.97 megagram per hectare (fresh weight basis) and incorporated into the bed before final bedding and laying of the drip tape and plastic mulch. Within each compost treatment, there were five fertigation treatments: organic high ( $200 \mathrm{mg} \mathrm{kg}^{-1} \mathrm{~N}$ from MultiBloom), organic low (100 $\mathrm{mg} \mathrm{kg}^{-1} \mathrm{~N}$ from MultiBloom), conventional high (200 $\mathrm{mg} \mathrm{kg}^{-1} \mathrm{~N}$ from Peter's 20-10-20), conventional low (100 $\mathrm{mg} \mathrm{kg}^{-1} \mathrm{~N}$ from Peter's 20-10-20), and control (no fertilizer). Each treatment combination included 10 zinnia plants that were planted $15 \mathrm{~cm}$ apart in two parallel rows in one bed, with $0.91 \mathrm{~m}$ space between each treatment combination. Each treatment combination was replicated three times. Starting on 20 April 2009, 12 days after transplanting, each plant was supplied with $200 \mathrm{~mL}$ of its assigned nutrient solution once a week for one month and then twice a week from late May through September.

On 4 May 2009, 26 days after transplanting, leaf greenness (chlorophyll content) was quantified using a SPAD-502 Chlorophyll Meter (Minolta Camera Co., Ramsey, NJ, USA). For each plant, three recently fully expanded leaves were randomly chosen for SPAD measurement and the average of the three readings was recorded. On the same date, plant growth index [(height + widest width + perpendicular width)/3] (PGI) was recorded. Zinnia stems were 
harvested as soon as the blooms were completely opened, starting from late April through September. The number of marketable stems longer than $30 \mathrm{~cm}$ was recorded.

Soil samples were taken on 28 May 2009 during peak plant growth, 50 days after transplanting. Soils were sampled to a $20 \mathrm{~cm}$ depth (root zone) using a $1.9-\mathrm{cm}$ diameter Oakfield probe. Four cores were taken randomly from each replicate plot to obtain approximately $100 \mathrm{~g}$ of fresh soil. Soil samples were sent to the Mississippi State University Soil Testing Laboratory (Mississippi State, MS, USA) for soil analyses. Samples were placed in a forced-draft air-drying cabinet and dried prior to grinding in a stainless steel grinder to pass through a 20-mesh sieve. A $5 \mathrm{~g}$ soil sample was extracted using Lancaster's soil testing method [32], and tested for the contents of soil extractable nutrients, including $\mathrm{P}, \mathrm{K}$, calcium (Ca), Mg, sodium ( $\mathrm{Na}$ ), and $\mathrm{Zn}$, using an inductively coupled plasma optical emission spectrometry (ICP-OES, Spectroblue, Spectro Analytical Instruments, Kleve, Germany). For soil $\mathrm{pH}, 20 \mathrm{~mL}$ deionized water was added to $10 \mathrm{~g}$ soil, and the mixture was shaken for $15 \mathrm{~min}$ before the soil-water suspension was determined for $\mathrm{pH}$ using a calibrated $\mathrm{pH}$ meter. Soil organic matter was estimated using $1 \mathrm{~g}$ of soil sample following the Debolt procedure [33].

The experiment was repeated in 2010 (Year 2). The same soil amendment and fertigation treatment was applied to the same plot to study the cumulative effects of the compost and fertigation on both plant growth and the soil. Zinnia seedlings grown in a standard 1206-cell pack were transplanted into raised beds in the high tunnel on 31 March 2010. Soil amendments were incorporated into the soil before laying the plastic mulch. Starting on 12 April 2010, 12 days after transplanting, each plant was supplied with $200 \mathrm{~mL}$ of nutrient solution from each fertigation treatment once a week for one month and then twice a week from mid-May through September. Plant growth index and SPAD readings were measured on 26 April 2010, 26 days after transplanting. Flower stems were harvested from late April through September 2010. Soil samples from each treatment combination was taken on 20 May 2010, 50 days after transplanting.

Data were analyzed by analysis of variance (ANOVA) using SAS (version 9.4; SAS Intitute, Cary, NC, USA). Repeated measures ANOVA was used to determine the year effects of fertilization treatments on soil nutrient levels as well as the interaction between year and compost/fertigation treatments over two year production. Comparisons of means among treatments were conducted using Fisher's protected Least Significant Difference test at $p \leq 0.05$.

\section{Results and Discussion}

\subsection{Plant Growth}

There was no interaction between the two main factors (compost and fertigation) on plant growth index (PGI) and leaf SPAD readings in either year of the study (Table 2). For PGI, there were significant main effects of compost in both years; however, fertigation did not influence PGI. For SPAD readings, there were significant main effects of fertigation in both years and compost effects in Year 1.

Compost had a significant effect on PGI in both years, suggesting that the pre-plant compost may have played an important role in providing nutrients for plant initial growth. For the three composts tested in this study, composted broiler litter produced the highest PGI in both years, followed by vermicompost and cotton gin compost (Table 3). Plants that did not receive any compost had the lowest PGI, similar to those that received cotton gin compost. Fertigation did not affect PGI. This could have resulted from the fact that PGI data were collected only two weeks after the fertigation treatment began, which may not have been enough time for the fertigation to alter plant size significantly. 
Table 2. Significance of pre-plant compost and fertigation during the growing season on plant growth index (PGI), leaf SPAD readings, and marketable stems per plant of zinnia "Benary's Giant Mix" grown in a high tunnel.

\begin{tabular}{ccccc}
\hline & $p$-Value (Year 1) & Significance $^{\mathbf{1}}$ & $\boldsymbol{p}$-Value (Year 2) & Significance \\
\hline Treatments & \multicolumn{4}{c}{ PGI } \\
\hline Compost & $<0.0001$ & S & 0.0006 & S \\
Fertigation & 0.128 & NS & 0.4449 & NS \\
Interaction & 0.160 & NS & 0.0553 & NS \\
\hline \multicolumn{5}{c}{ SPAD } \\
\hline Compost & $<0.0001$ & S & 0.0734 & NS \\
Fertigation & 0.0024 & S & 0.0193 & \\
Interaction & 0.3367 & NS & 0.7558 & NS \\
\hline Compost & 0.2156 & Marketable Stems per Plant & \\
Fertigation & 0.0004 & NS & 0.1610 & NS \\
Interaction & 0.7658 & S & 0.2005 & 0.0715 \\
\hline
\end{tabular}

${ }^{1} \mathrm{~S}=$ Significant main effects or the interaction between the two main factors (compost and fertigation) suggested by ANOVA at $p \leq 0.05 ; \mathrm{NS}=$ non-significant. ${ }^{2}$ Marketable stems $=$ stems longer than $30 \mathrm{~cm}$.

Table 3. Effects of pre-plant compost incorporation on plant growth index (PGI) and leaf SPAD readings of zinnia "Benary's Giant Mix" grown in a high tunnel. Data were taken 26 days after transplanting in both years.

\begin{tabular}{cccc}
\hline & \multicolumn{2}{c}{ PGI (cm) } & SPAD \\
\hline Compost & Year 1 & Year 2 & Year 1 \\
\hline Composted Broiler & $19.2 \mathrm{a}^{1}$ & $31.5 \mathrm{a}$ & $34.3 \mathrm{a}$ \\
Litter & $17.3 \mathrm{~b}$ & $27.8 \mathrm{~b}$ & $32.4 \mathrm{~b}$ \\
Vermicompost & $16.7 \mathrm{bc}$ & $25.3 \mathrm{c}$ & $32.3 \mathrm{bc}$ \\
Cotton Gin Compost & $16.0 \mathrm{c}$ & $25.5 \mathrm{c}$ & $31.4 \mathrm{c}$ \\
No Compost & &
\end{tabular}

${ }^{1}$ Different lowercase letters within a column indicate significant difference among means suggested by Fisher's protected LSD at $p \leq 0.05$.

For SPAD readings, regardless of fertigation, plants that received composted broiler litter had the highest SPAD reading, and plants that did not receive any compost had the lowest SPAD in Year 1 (Table 3). Compost did not affect SPAD readings in Year 2. Regardless of compost treatment, plants that received high rates of either organic or conventional fertilizer had higher SPAD readings than those that received conventional low or no fertilizer in Year 1 (Table 4). In Year 2, both rates of conventional fertilizer produced higher SPAD readings than the no fertilizer control; however, both rates of organic fertilizer had similar SPAD readings to the no fertilizer control. There was no difference in SPAD readings between the two rates of organic or conventional fertilizer. SPAD readings measure the greenness of the leaves, which were found to be highly correlated to chlorophyll content and sometimes correlated to plant $\mathrm{N}$ status depending on plant species [34-36]. Therefore, this nondestructive measure of chlorophyll content using the SPAD meter is used as guidance for fertilization applications. In this study, SPAD data were collected about four weeks after zinnia plants were planted and after two fertigation events to compare the relative status of the vegetative growth of zinnia plants. Overall, the SPAD readings we found were comparable to those reported in healthy zinnia leaves by Niu et al. [37]. 
Table 4. Effects of fertigation during the growing season on leaf SPAD readings (taken 26 days after transplanting in both years) and number of marketable stems per plant of zinnia “Benary's Giant Mix" grown in a high tunnel.

\begin{tabular}{cccc}
\hline Fertigation $\mathbf{1}^{\mathbf{1}}$ & $\begin{array}{c}\text { SPAD } \\
\text { (Year 1) }\end{array}$ & $\begin{array}{c}\text { SPAD } \\
\text { (Year 2) }\end{array}$ & $\begin{array}{c}\text { Marketable Stems } \\
\text { per Plant (Year 1) }\end{array}$ \\
\hline Organic High & $33.4 \mathrm{a}^{2}$ & $38.3 \mathrm{abc}$ & $27.1 \mathrm{a}$ \\
Organic Low & $32.7 \mathrm{ab}$ & $37.8 \mathrm{bc}$ & $23.1 \mathrm{~b}$ \\
Conventional High & $33.4 \mathrm{a}$ & $38.6 \mathrm{ab}$ & $26.0 \mathrm{ab}$ \\
Conventional Low & $32.0 \mathrm{~b}$ & $38.9 \mathrm{a}$ & $23.7 \mathrm{~b}$ \\
No Fertilizer & $31.5 \mathrm{~b}$ & $37.8 \mathrm{c}$ & $16.6 \mathrm{c}$ \\
\hline
\end{tabular}

${ }^{1}$ Organic High $=200 \mathrm{mg} \mathrm{kg}^{-1} \mathrm{~N}$ from a liquid catfish organic fertilizer (MultiBloom); Organic Low $=100 \mathrm{mg}$ $\mathrm{kg}^{-1} \mathrm{~N}$ from MultiBloom; Conventional High $=200 \mathrm{mg} \mathrm{kg}^{-1} \mathrm{~N}$ from Peter's 20-10-20 water soluble fertilizer; Conventional Low $=100 \mathrm{mg} \mathrm{kg}^{-1} \mathrm{~N}$ from Peter's 20-10-20. ${ }^{2}$ Different lowercase letters within a column indicate significant difference among means suggested by Fisher's protected LSD at $p \leq 0.05 .{ }^{3}$ Marketable stems $=$ stems longer than $30 \mathrm{~cm}$.

\subsection{Marketable Yield of Zinnia Cut Flower Stems}

There was no interaction effect between compost and fertigation on marketable yield of zinnia cut stems in either year (Table 2). Compost treatment did not impact marketable yield of zinnia cuts in either year. However, in Year 1, fertigation influenced the number of marketable stems per plant. Plants that received a high rate of organic fertilizer produced a comparable number of stems to plants that received the conventional high rate, but produced more stems than plants that received the low rate of either conventional or organic fertilizer (Table 4). Plants that did not receive any fertigation produced the lowest number of marketable stems (Table 4).

Similar levels of $\mathrm{N}$ from both the conventional and organic fertilizer tested in this study produced a comparable number of marketable flower stems, suggesting that the mineralization rate of the liquid fish organic fertilizer used in this study is high enough to make the nutrients available to zinnia plants during the season. Hartz et al. [38] reported that a liquid fish-based organic fertilizer had a relatively high mineralization rate, where $79 \%$ to $93 \%$ of the total $\mathrm{N}$ were transformed to mineral $\mathrm{N}$ in the soil after 1 week, and $83 \%$ to $99 \%$ after 4 weeks in an incubation study. A liquid fish fertilizer was shown to be an acceptable organic alternative to inorganic soluble fertilizer in cranberry production [39], but another similar product led to reduced yield on "Delicious" and "Golden Delicious" apples when applied as a foliar fertilizer [40]. Using a fish fertilizer as opposed to a conventional fertilizer of comparative N-P-K level was found to produce quality radish and cucumber plants and have a disease suppression effect over soil-borne pathogens, such as Rhizoctonia and Pythium, by creating a biological climate in peat substrate or soil that is suppressive to the disease [41]. Since similar rates of the conventional and organic fertilizers used in this study produced similar yield, the organic fish fertilizer can be used as an alternative to conventional fertilizer for cut flower production of zinnia.

In Year 2, stem number per plant was not influenced by either compost or the fertigation treatments, with an average of 5.3 marketable stems $(>30 \mathrm{~cm})$ per plant, which possibly resulted from the severe powdery mildew disease during that growing season. Occurrence of the disease decreased the flowering performance of the zinnia plants from all treatments and therefore might have neutralized the difference among treatments. The majority of flower stems in Year 2 fell into the 20 to $30 \mathrm{~cm}$ range, instead of being more than $30 \mathrm{~cm}$ in length, which was the standard we used in this study for marketable yield. On average, each plant produced 21.2 flower stems that were more than $20 \mathrm{~cm}$ in length with no difference among compost or fertigation treatments (data not shown). Compared to an average of 23.3 marketable stems per plant in Year 1 , disease had severely reduced marketable yield. Outbreaks of disease such as powdery mildew can result from improper plant spacing, overhead irrigation, poor air circulation or watering too late during the day [42]. It was reported that powdery mildew was severe on strawberries grown under tunnels compared to field production, especially with a susceptible cultivar [43]. Increasing 
spacing or selectively pruning the over-crowded brunches may be considered so as to improve air circulation under high tunnels to prevent disease such as powdery mildew [44,45]. There are also chemical controls that can be used to reduce powdery mildew incidence, as well as biocontrol agents that can be applied as substitutes to synthetic chemical fungicides to reduce unwanted chemical residues on the cut flowers of zinnia in organic and similarly managed systems [46].

\subsection{Soil Analyses}

There were no significant interaction effects between compost and fertigation on soil nutrients, organic matter, and $\mathrm{pH}$. Compost treatments affected soil-extractable $\mathrm{P}$, $\mathrm{K}, \mathrm{Ca}, \mathrm{Mg}, \mathrm{Zn}$, and $\mathrm{Na}$ concentrations and $\mathrm{pH}$, but had no influence on soil organic matter and $\mathrm{S}$ concentration in both years (Table 5). Soil that received composted broiler litter had significantly higher levels of extractable $\mathrm{P}, \mathrm{K}, \mathrm{Zn}$, and $\mathrm{Na}$ in both years and $\mathrm{Mg}$ in Year 2 in comparison to those that received other compost treatments. Soil treated with vermicompost had higher $\mathrm{pH}$ and extractable Ca levels in both years, but a lower extractable $\mathrm{Na}$ level in Year 1 compared to the other compost treatments. However, in both years, soil $\mathrm{pH}$ was within the appropriate range of 5.5-6.5 for growing zinnia [23,42]. Among all the nutrient elements affected by the compost treatments, a higher concentration of a given element in the soil was consistent with the higher level of that specific element introduced by a given compost source (Tables 1 and 5 ), suggesting that repeated application of the composts as organic amendments may lead to the buildup of certain elements or salts. Due to the exclusion of rainfall that allows excess nutrients to leach out of the soil, there is concern that soil quality will deteriorate under high tunnels resulting from the accumulation of nutrient salts.

Table 5. Soil-extractable nutrient levels and soil $\mathrm{pH}$ in a high tunnel production of zinnia "Benary's Giant Mix" in response to pre-plant compost treatments. Data were taken 50 days after transplanting in both years.

\begin{tabular}{|c|c|c|c|c|c|c|c|c|c|c|}
\hline \multirow[t]{2}{*}{ Compost } & \multicolumn{2}{|c|}{$\begin{array}{c}\mathrm{P}^{1,2} \\
\mathrm{mg} \mathrm{kg}^{-1}\end{array}$} & \multicolumn{2}{|c|}{$\begin{array}{c}\mathrm{K} \\
\mathrm{mg} \mathrm{kg}^{-1}\end{array}$} & \multicolumn{2}{|c|}{$\begin{array}{c}\mathrm{Ca} \\
\mathrm{mg} \mathrm{kg}^{-1}\end{array}$} & \multicolumn{2}{|c|}{$\frac{\mathrm{Mg}}{\mathrm{mg} \mathrm{kg}^{-1}}$} & \multicolumn{2}{|c|}{$\begin{array}{c}\mathrm{S} \\
\mathrm{mg} \mathrm{kg}^{-1}\end{array}$} \\
\hline & Year 1 & Year 2 & Year 1 & Year 2 & Year 1 & Year 2 & Year 1 & Year 2 & Year 1 & Year 2 \\
\hline $\begin{array}{l}\text { Composted } \\
\text { Broiler Litter }\end{array}$ & $39.9 \mathrm{aB}$ & $67.8 \mathrm{aA}$ & $127.6 \mathrm{a}$ & $116.7 \mathrm{a}$ & $975.7 \mathrm{~b}$ & $1067.1 \mathrm{~b}$ & $141.0 \mathrm{a}$ & $152.0 \mathrm{a}$ & 46.8 & 47.6 \\
\hline Vermicompost & $25.0 \mathrm{bB}$ & $32.3 \mathrm{bA}$ & $92.3 \mathrm{~b}$ & 73.9 bc & $1103.5 \mathrm{a}$ & $1203.9 \mathrm{a}$ & $139.5 \mathrm{a}$ & $136.2 \mathrm{~b}$ & 52.6 & 49 \\
\hline $\begin{array}{c}\text { Cotton Gin } \\
\text { Compost }\end{array}$ & $24.1 \mathrm{bA}$ & $27.7 \mathrm{bA}$ & $98 \mathrm{~b}$ & $77.2 \mathrm{~b}$ & $975.1 \mathrm{~b}$ & 1017.7 b & $127.9 \mathrm{~b}$ & $118.8 \mathrm{c}$ & 42.4 & 43.4 \\
\hline No Compost & $24.2 \mathrm{bB}$ & $28.6 \mathrm{bA}$ & $87.6 \mathrm{~b}$ & $68.5 c$ & $991.9 \mathrm{~b}$ & $1003.5 \mathrm{~b}$ & $148.7 \mathrm{a}$ & $138.3 b$ & 47.5 & 46.2 \\
\hline Significance ${ }^{3}$ & $S$ & $S$ & $S$ & $S$ & $S$ & $S$ & $S$ & $S$ & NS & NS \\
\hline \multirow[t]{2}{*}{ Compost } & \multicolumn{2}{|c|}{$\begin{array}{c}\mathrm{Zn} \\
\mathrm{mg} \mathrm{kg}^{-1}\end{array}$} & \multicolumn{2}{|c|}{$\begin{array}{c}\mathrm{Na} \\
\mathrm{mg} \mathrm{kg}^{-1}\end{array}$} & \multicolumn{2}{|c|}{$\begin{array}{c}\text { Organic Matter } \\
\%\end{array}$} & \multicolumn{2}{|c|}{$\mathrm{pH}$} & & \\
\hline & Year 1 & Year 2 & Year 1 & Year 2 & Year 1 & Year 2 & Year 1 & Year 2 & & \\
\hline $\begin{array}{l}\text { Composted } \\
\text { Broiler Litter }\end{array}$ & $1.19 \mathrm{aB}$ & $1.80 \mathrm{aA}$ & $76 \mathrm{a}$ & $86.4 \mathrm{a}$ & 0.65 & 0.66 & $5.88 \mathrm{~b}$ & $6.00 \mathrm{~b}$ & & \\
\hline Vermicompost & $0.84 \mathrm{bA}$ & $0.77 \mathrm{bA}$ & $52.8 \mathrm{c}$ & $58.3 \mathrm{~b}$ & 0.77 & 0.68 & $6.21 \mathrm{a}$ & $6.32 \mathrm{a}$ & & \\
\hline $\begin{array}{l}\text { Cotton Gin } \\
\text { Compost }\end{array}$ & $0.73 \mathrm{bA}$ & $0.65 \mathrm{bA}$ & $62.6 \mathrm{~b}$ & $61.1 \mathrm{~b}$ & 0.59 & 0.6 & $5.84 \mathrm{~b}$ & $5.97 \mathrm{~b}$ & & \\
\hline No Compost & $0.81 \mathrm{bA}$ & $0.78 \mathrm{bA}$ & $52.8 \mathrm{c}$ & $62.8 \mathrm{~b}$ & 0.66 & 0.64 & $5.73 \mathrm{~b}$ & $6.00 \mathrm{~b}$ & & \\
\hline Significance & S & S & $\mathrm{S}$ & $\mathrm{S}$ & NS & NS & S & S & & \\
\hline
\end{tabular}

${ }^{1} \mathrm{P}$ = phosphorus; $\mathrm{K}=$ potassium; $\mathrm{Ca}=$ calcium; $\mathrm{Mg}=$ magnesium; $\mathrm{S}=$ sulfur; $\mathrm{Zn}=$ zinc; $\mathrm{Na}=$ sodium. ${ }^{2}$ Different lowercase letters within a column indicate significant difference among means by Fisher's protected LSD at $p \leq 0.05$. Means with different capitalized letters in a row under a given nutrient are significantly different between years by Fisher's protected LSD at $p \leq 0.05$. ${ }^{3} \mathrm{~S}=$ Significant at $p \leq 0.05$; NS $=$ non-significant.

Fertigation treatments affected soil-extractable levels of $P$ in both years, Na in Year 2, and $\mathrm{pH}$ in Year 2, but had no influence on soil $\mathrm{K}, \mathrm{Ca}, \mathrm{Mg}, \mathrm{S}, \mathrm{Zn}$, and organic matter in both years (Table 6). The Organic High treatment resulted in lower soil $\mathrm{pH}$ compared to other treatments in Year 2 but not in Year 1. It also resulted in higher soil P levels than 
the Conventional Low treatment and no fertilizer control in Year 2. A comparable rate of organic and conventional fertilizers resulted in similar soil $\mathrm{P}$ levels across both years, where low rates of both fertilizers led to similar levels of $P$ to the no fertilizer treatment in Year 1 (Table 6). The Organic and Conventional High treatments led to somewhat lower soil Na levels in Year 2 than the Organic Low treatment, with the No Fertilizer Control and the Conventional Low leading to intermediate levels indistinguishable from soil Na levels in the other treatments (Table 6).

Table 6. Soil-extractable nutrient levels and soil pH in a high tunnel production of zinnia "Benary's Giant Mix" in response to fertigation treatments. Data were taken 50 days after transplanting in both years.

\begin{tabular}{|c|c|c|c|c|c|c|c|c|c|c|}
\hline \multirow[t]{2}{*}{ Fertigation $^{1}$} & \multicolumn{2}{|c|}{$\begin{array}{c}\mathrm{P}^{2,3} \\
\mathrm{mg} \mathrm{kg}^{-1}\end{array}$} & \multicolumn{2}{|c|}{$\begin{array}{c}\mathrm{K} \\
\mathrm{mg} \mathrm{kg}^{-1}\end{array}$} & \multicolumn{2}{|c|}{$\begin{array}{c}\mathrm{Ca} \\
\mathrm{mg} \mathrm{kg}^{-1}\end{array}$} & \multicolumn{2}{|c|}{$\begin{array}{c}\mathrm{Mg} \\
\mathrm{mg} \mathrm{kg}^{-1}\end{array}$} & \multicolumn{2}{|c|}{$\begin{array}{c}\mathrm{S} \\
\mathrm{mg} \mathrm{kg}^{-1}\end{array}$} \\
\hline & Year 1 & Year 2 & Year 1 & Year 2 & Year 1 & Year 2 & Year 1 & Year 2 & Year 1 & Year 2 \\
\hline Organic High & $30.0 \mathrm{ab}$ & $47.3 \mathrm{a}$ & 99.3 & 85.5 & 1015.7 & 1037.5 & 137.8 & 131.0 & 48.2 & 47.5 \\
\hline Organic Low & $24.9 \mathrm{c}$ & $43.3 \mathrm{ab}$ & 102.9 & 88.5 & 992.3 & 1120.8 & 139.8 & 142.9 & 47.1 & 47.9 \\
\hline Conventional High & $31.7 \mathrm{a}$ & $37.7 \mathrm{abc}$ & 103.6 & 85.5 & 1036.5 & 1080.4 & 138.3 & 135.5 & 47.4 & 44.3 \\
\hline Conventional Low & $29.3 a b c$ & $35.3 \mathrm{bc}$ & 101.4 & 81.5 & 1004.6 & 1050.2 & 135.4 & 131.6 & 50.0 & 45.5 \\
\hline No Fertilizer & $25.6 \mathrm{bc}$ & $32.0 \mathrm{c}$ & 99.7 & 79.3 & 1008.8 & 1076.3 & 145.3 & 140.7 & 43.8 & 47.5 \\
\hline Significance ${ }^{4}$ & $S$ & $S$ & NS & NS & NS & NS & NS & NS & NS & NS \\
\hline \multirow[t]{2}{*}{ Fertigation } & \multicolumn{2}{|c|}{$\begin{array}{c}\mathrm{Zn} \\
\mathrm{mg} \mathrm{kg}^{-1}\end{array}$} & \multicolumn{2}{|c|}{$\begin{array}{c}\mathrm{Na} \\
\mathrm{mg} \mathrm{kg}^{-1}\end{array}$} & \multicolumn{2}{|c|}{$\begin{array}{c}\text { Organic Matter } \\
\%\end{array}$} & \multicolumn{2}{|c|}{$\mathrm{pH}$} & & \\
\hline & Year 1 & Year 2 & Year 1 & Year 2 & Year 1 & Year 2 & Year 1 & Year 2 & & \\
\hline Organic High & 0.89 & 1.09 & 64.5 & $63.8 \mathrm{~b}$ & 0.67 & 0.66 & 5.92 & $5.93 \mathrm{~b}$ & & \\
\hline Organic Low & 0.80 & 1.05 & 64.4 & $73.0 \mathrm{a}$ & 0.71 & 0.67 & 5.88 & $6.13 \mathrm{a}$ & & \\
\hline Conventional High & 1.01 & 0.95 & 59.3 & $63.8 \mathrm{~b}$ & 0.66 & 0.62 & 5.97 & $6.07 \mathrm{ab}$ & & \\
\hline Conventional Low & 0.91 & 0.97 & 58.9 & $67.2 \mathrm{ab}$ & 0.70 & 0.63 & 5.99 & $6.09 \mathrm{a}$ & & \\
\hline No Fertilizer & 0.87 & 0.94 & 58.1 & $67.9 \mathrm{ab}$ & 0.61 & 0.66 & 5.83 & $6.16 \mathrm{a}$ & & \\
\hline Significance & NS & NS & NS & $\mathrm{S}$ & NS & NS & NS & $S$ & & \\
\hline
\end{tabular}

Repeated measures ANOVA showed that the year effect was significant for soilextractable $\mathrm{P}, \mathrm{K}, \mathrm{Zn}$, and $\mathrm{Na}$ concentrations and $\mathrm{pH}$, and that there was an interaction between year and compost treatments in P and Zn concentrations (Table 5). Higher soil P concentrations were found in Year 2 compared to Year 1 from the composted broiler litter, vermicompost, and no compost treatments, with no difference between the two years for cotton gin compost. A higher $\mathrm{Zn}$ concentration in Year 2 resulted from composted broiler litter, with no difference between the two years under other composts or the no compost treatments. K concentration was lower in Year 2 than in Year 1, whereas Na concentration and $\mathrm{pH}$ were higher in the soil in Year 2 than in Year 1 (Table 7).

Table 7. Average soil nutrient levels over two growing seasons, across compost and fertigation treatments, in a high tunnel production of zinnia "Benary's Giant Mix". Data were taken 50 days after transplanting in both years.

\begin{tabular}{cccc}
\hline & $\mathbf{K}^{\mathbf{1 , 2}}$ & $\mathbf{N a}$ & $\mathbf{p H}$ \\
\hline $\mathbf{m g ~ k g}^{\mathbf{- 1}}$ & $\mathbf{m g ~ k g}^{-\mathbf{1}}$ & \\
\hline Year 1 & $101.4 \mathrm{a}$ & $61.1 \mathrm{~b}$ & $5.92 \mathrm{~b}$ \\
Year 2 & $84.1 \mathrm{~b}$ & $67.2 \mathrm{a}$ & $6.07 \mathrm{a}$ \\
\hline
\end{tabular}

${ }^{1} \mathrm{~K}=$ potassium; $\mathrm{Na}=$ sodium. ${ }^{2}$ Different lowercase letters within a column indicate significant difference between means by Fisher's protected LSD at $p \leq 0.05$.

Over-fertilization can pose a potential threat to high tunnel production by reducing plant quality and increasing plants' susceptibility to diseases [47], since there is often little if any leaching of nutrients. The idea of using pre-plant organic amendments in combination with different fertigation treatments during the growing season was to provide sufficient fertility for zinnia plants to produce a profitable number of stems while maintaining healthy 
soil properties and avoiding over-fertilization. Generally, available soil K was low-medium in Year 1 and actually decreased further in Year 2 (Table 7), suggesting more K fertilization may have been needed for most treatments to maintain the soil fertility. On the other hand, $\mathrm{Zn}$ and $\mathrm{P}$ increased in Year 2 due to certain compost treatments, and Na increased in Year 2 in general (Tables 5 and 7). Zn concentrations in soil were fairly high in Year 2 due to the broiler litter treatment. Therefore, build-up of $\mathrm{Zn}$ over years should be paid close attention so as to avoid any possible $\mathrm{Zn}$ toxicity. Increasing $\mathrm{P}$ in the soil to a degree can be beneficial to soil fertility maintenance. However, repeated applications of broiler litter to fields can increase soil $\mathrm{P}$ to levels well above those necessary for plant growth $[18,48,49]$. If after only two years we observed changes in soil nutrient levels, it would be interesting to see how the soil quality changes, either in physical, chemical, or biological properties, after relatively long-term application of the organic amendments in combination with different levels of fertigation (either organic or conventional).

\section{Conclusions}

Pre-plant compost did not influence the total number of marketable stems produced in zinnia plants grown in a high tunnel. However, compost affected plant growth index and leaf SPAD readings early in the growing season. Among the pre-plant composts tested in this study, composted broiler litter produced the largest plant size and the highest leaf SPAD readings. Fertigation during the growing season influenced the number of marketable stems, with higher rates of both organic and conventional fertilizers producing more stems than lower rates and no fertilizer control. There was no difference in the marketable stems produced by comparable rates of organic or conventional fertilizer, suggesting the liquid fish fertilizer used in this study can serve as an alternative source of fertilizer for organic or sustainable production of zinnia cut flowers, with potential benefits of improving soil health in the long run. However, growers should pay close attention to the potential buildup of salts or changes in soil $\mathrm{pH}$ caused by some sources of compost or organic fertilizer. Further investigation of different types and rates of composts and organic fertilizers suitable for various crop systems as well as their long-term effects will help provide more precise information to maximize crop yield and improve soil quality through the efficient application of organic fertilizer combined with compost amendments.

Author Contributions: Conceptualization, G.B. and W.B.E.; investigation, G.B., T.L., W.B.E., M.G. and M.W.; writing — original draft preparation, T.L. and G.B.; writing—review and editing, W.B.E., M.G. and M.W.; funding acquisition, G.B., W.B.E., M.G. and M.W. All authors have read and agreed to the published version of the manuscript.

Funding: This work was supported by the Mississippi State University Agricultural and Forestry Experiment Station Strategic Research Initiative and the United States Department of Agriculture (USDA) National Institute of Food and Agriculture Hatch Project MIS-249180. Mention of a trademark, proprietary product, or vendor does not constitute a guarantee or warranty of the product by Mississippi State University or the USDA and does not imply its approval to the exclusion of others.

Conflicts of Interest: The authors declare no conflict of interest.

\section{References}

1. Lamont, W.J.; McGann, M.; Orzolek, M.; Mbugua, N.; Dye, B.; Reese, D. Design and construction of the Penn State high tunnel. HortTechnology 2002, 12, 447-453. [CrossRef]

2. Lamont, W.J. Overview of the use of high tunnels worldwide. HortTechnology 2009, 19, 25-29. [CrossRef]

3. Lamont, W.J. Plastics: Modifying the microclimate for the production of vegetable crops. HortTechnology 2005, 15, 477-481. [CrossRef]

4. Lamont, W.J.; Orzolek, M.D.; Holcomb, E.J.; Demchak, K.; Burkhart, E.; White, L.; Dye, B. Production system for horticultural crops grown in Penn State high tunnel. HortTechnology 2003, 13, 358-362. [CrossRef]

5. Lang, G.A. High tunnel tree fruit production: The final frontier? HortTechnology 2009, 19, 50-55. [CrossRef]

6. Wien, H.C. Floral crop production in high tunnels. HortTechnology 2009, 19, 56-60. [CrossRef]

7. Wittwer, S. World-wide use of plastics in horticultural production. HortTechnology 1993, 3, 6-19. [CrossRef] 
8. Carey, E.E.; Jett, L.; Lamont, W.J.; Nennich, T.T.; Orzolek, M.D.; Williams, K.A. Horticultural crop production in high tunnels in the United States: A snapshot. HortTechnology 2009, 19, 37-43. [CrossRef]

9. Guan, W.; Haseman, D.; Nowaskie, D. Rootstock evaluation for grafted cucumbers grown in high tunnels: Yield and plant growth. HortScience 2020, 55, 914-919. [CrossRef]

10. Izaba, R.F.R.; Guan, W.; Torres, A.P. Economic analysis of growing grafted cucumber plants for high tunnel production. HortTechnology 2021, 31, 181-187. [CrossRef]

11. Panter, K.L.; Gergeni, T.M.; Seals, C.P.; Garfinkel, A.R. Orientation of small hobby high tunnels and potential effects on cut sunflowers and fresh herbs. HortTechnology 2019, 29, 461-467. [CrossRef]

12. Santos Hecher, E.A.; Constance, L.F.; Enfield, J.; Guldan, S.J.; Uchanski, M.E. The economics of low-cost high tunnels for winter vegetable production in the Southwestern United States. HortTechnology 2014, 24, 7-15. [CrossRef]

13. Yao, S.; Guldan, S.; Heyduck, R. High tunnel apricot production in frost-prone Northern New Mexico. HortTechnology 2019, 29, 457-460. [CrossRef]

14. Zhao, Y.; Gu, M.; Bi, G.; Evans, W.B.; Harkess, R. Planting date effect on yield of tomato, eggplant, pepper, zinnia, and snapdragon in high tunnel in Mississippi. J. Crop Improv. 2014, 28, 27-37. [CrossRef]

15. Zhao, X.; Carey, E.E. Summer production of lettuce, and microclimate in high tunnel and open field plots in Kansas. HortTechnology 2009, 19, 113-119. [CrossRef]

16. Knewtson, S.J.B.; Kirkham, M.B.; Janke, R.R.; Murray, L.W.; Carey, E.E. Soil quality after eight years under high tunnels. HortScience 2012, 47, 1630-1633. [CrossRef]

17. Montri, A.; Biernbaum, J.A. Management of the soil environment in high tunnels. HortTechnology 2009, 19, 34-36. [CrossRef]

18. Reeve, J.; Drost, D. Yields and soil quality under transitional organic high tunnel tomatoes. HortScience 2012, 47, 38-44. [CrossRef]

19. Dumanski, J.; Pieri, C. Land quality indicators: Research plan. Agric. Ecosyst. Environ. 2000, 81, 93-102. [CrossRef]

20. Aggelides, S.M.; Londra, P.A. Effects of compost produced from town wastes and sewage sludge on the physical properties of a loamy and clay soil. Bioresour. Technol. 2000, 71, 253-259. [CrossRef]

21. Celik, I.; Ortas, I.; Kilic, S. Effects of compost, mycorrhiza, manure and fertilizer on some physical properties of a chromoxerert soil. Soil Till. Res. 2004, 66, 97-205. [CrossRef]

22. Marinari, S.; Masciandaro, G.; Ceccanti, B.; Grego, S. Influence of organic and mineral fertilizers on soil biological and physical properties. Bioresour. Technol. 2000, 72, 9-17. [CrossRef]

23. Havlin, J.L.; Tisdale, S.L.; Nelson, W.L.; Beaton, J.D. Soil Fertility and Fertilizers: An Introduction to Nutrient Management, 8th ed.; Pearson: London, UK, 2013.

24. Gaskell, M.; Smith, R. Nitrogen sources for organic vegetable crops. HortTechnology 2007, 17, 431-441. [CrossRef]

25. Gravel, V.; Dorais, M.; Ménard, C. Organic fertilization and its effect on development of sweet pepper transplants. HortScience 2012, 47, 198-204. [CrossRef]

26. Bi, G.; Evans, W.B.; Spiers, J.M.; Withcher, A.L. Effects of organic and inorganic fertilizers on marigold growth and flowering. HortScience 2010, 45, 1373-1377. [CrossRef]

27. Larco, H.; Strik, B.C.; Bryla, D.R.; Sullivan, D.M. Mulch and fertilizer management practices for organic production of highbush blueberry. I: Plant growth and allocation of biomass during establishment. HortScience 2013, 48, 1250-1261. [CrossRef]

28. Granitz, H.M. Improving the North Carolina Cut Flower Industry: A Production and Marketing Survey, Field and Postharvest Cut Flower Variety Evaluations, and Preemergence Herbicide Trials on Unlabeled Cut Flower Crops. Master's Thesis, North Carolina State University, Raleigh, NC, USA, 2014.

29. Loyola, C.E.; Dole, J.M.; Dunning, R. North American specialty cut flower production and postharvest survey. HortTechnology 2019, 29, 338-359. [CrossRef]

30. Association of Specialty Cut Flower Growers (ASCFG). Available online: https://www.ascfg.org/ (accessed on 20 July 2021).

31. Ortiz, M.A.; Hyrczyk, K.; Lopez, R.G. Comparison of high tunnel and field production of specialty cut flowers in the Midwest. HortScience 2012, 47, 1265-1269. [CrossRef]

32. Lancaster, J.D. Mississippi Soil Test Method and Interpretation; Mississippi Agricultural Experiment Station Mimeograph: Mississippi State, MS, USA, 1980.

33. Debolt, D.C. A high sample volume procedure for the colorimetric determination of soil organic matter. Comm. Soil Sci. Plant Analy. 1974, 5, 131-137. [CrossRef]

34. Jifon, J.L.; Syvertsen, J.P.; Whaley, E. Growth environment and leaf anatomy affect nondestructive estimates of chlorophyll and nitrogen in Citrus sp. leaves. J. Am. Soc. Hort. Sci. 2005, 130, 152-158. [CrossRef]

35. Kim, S.H.; Jeong, J.H.; Nackley, L.L. Photosynthetic and transpiration responses to light, $\mathrm{CO}_{2}$, temperature, and leaf senescence in garlic: Analysis and modeling. J. Am. Soc. Hort. Sci. 2013, 138, 149-156. [CrossRef]

36. Netto, A.T.; Campostrini, E.; Oliveira, J.G.; Bressan-Smith, R.E. Photosynthetic pigments, nitrogen, chlorophyll $\alpha$ fluorescence and SPAD-502 readings in coffee leaves. Sci. Hort. 2005, 104, 199-209. [CrossRef]

37. Niu, G.; Wang, M.; Rodriguez, D.; Zhang, D. Response of zinnia plants to saline water irrigation. HortScience 2012, 47, 793-797. [CrossRef]

38. Hartz, T. Nitrogen availability from liquid organic fertilizers. Hort. Technol. 2010, 20, 169-172. [CrossRef]

39. DeMoranville, C. Fish hydrolysate fertilizer: Its potential role in commercial production. HortScience 1990, 25, 626. [CrossRef] 
40. Schupp, J.R.; Schupp, H.A.; Bates, M.H. Effects of foliar applications of fish hydrolysate fertilizer or urea on apple yield and quality. HortScience 1993, 28, 254. [CrossRef]

41. Abbasi, P.A.; Conn, K.L.; Lazarovits, G. Suppression of Rhizoctonia and Pythium damping-off of radish and cucumber seedlings by addition of fish emulsion to peat mix or soil. Can. J. Plant Pathol. 2004, 26, 177-187. [CrossRef]

42. Johnson, C.N.; Kessler, J.R. Greenhouse Production of Bedding Plant Zinnias; The Alabama Cooperative Ext. System: Auburn, AL, USA, 2007; ANR-1311. Available online: https://ssl.acesag.auburn.edu/pubs/docs/A/ANR-1311/ANR-1311-archive.pdf (accessed on 20 July 2021).

43. Xiao, C.L.; Chandler, C.K.; Price, J.F.; Duval, J.R.; Mertely, J.C.; Legard, D.E. Comparison of epidemics of Botrytis fruit rot and Powdery mildew of strawberry in large plastic tunnels and field production systems. Plant Dis. 2001, 85, 901-909. [CrossRef] [PubMed]

44. Newman, S.; Pottorff, L.P. Powdery Mildews; Colorado State University Ext.: Fort Collins, CO, USA, 2013; No. 2.902. Available online: https:/ / extension.colostate.edu/docs/pubs/garden/02902.pdf (accessed on 20 July 2021).

45. Wyenandt, A.; Kline, W.; Both, A.J. Important Diseases of Tomatoes Grown in High Tunnels and Greenhouses in New Jersey; Rutgers, The State University of New Jersey Cooperative Ext.: New Brunswick, NJ, USA, 2020; FS358. Available online: https:/ /njaes. rutgers.edu/fs358/ (accessed on 20 July 2021).

46. Pertot, I.; Zasso, R.; Amsalem, L.; Baldessari, M.; Angeli, G.; Elad, Y. Integrating biocontrol agents in strawberry powdery mildew control strategies in high tunnel growing systems. Crop Prot. 2008, 27, 622-631. [CrossRef]

47. Magdoff, F.; van Es, H. Building Soils for Better Crops, 4th ed.; University of Maryland: College Park, MD, USA, 2000. Available online: https:/ / www.sare.org/wp-content/uploads/Building-Soils-for-Better-Crops.pdf (accessed on 20 July 2021).

48. Reddy, K.C.; Reddy, S.S.; Malik, R.K.; Lemunyon, J.L.; Reeves, D.W. Effect of five-year continuous poultry litter use in cotton production on major soil nutrients. Agron. J. 2008, 100, 1047-1055. [CrossRef]

49. Rosen, C.J.; Allan, D.L. Exploring the benefits of organic nutrient sources for crop production and quality: A review. HortTechnology 2007, 17, 422-430. [CrossRef] 